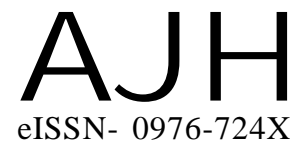

Received : 26.08.2016

Revised : 01.10.2016

Accepted : 15.10 .2016
Members of the Research Forum

Associated Authors:

'Department of Horticulture, Faculty of Agriculture, Annamalai

University, Annamalai Nagar, CHIDAMBARAM (T.N.) INDIA
Author for correspondence : E. ARIVAZHAGAN

Department of Horticulture, Faculty

of Agriculture, Annamalai

University, Annamalai Nagar,

CHIDAMBARAM (T.N.) INDIA
THEASIAN JOURNAL OF HORTICULTURE

Volume 11 | Issue 2 | December, 2016 |261-268

Visit us -www.researchjournal.co.in

RESEARCH PAPER

\title{
Influence of plant growth regulators and Azospirillum on rooting of air layers in guava (Psidium guajava L.)
}

\section{ANANDHANAMBI ${ }^{1}$, E. ARIVAZHAGAN AND R. KANDASAMY ${ }^{1}$}

ABSTRACT : Investigation was carried out on air layering in guava as influenced by growth regulators and Azospirillum was carried out in the Orchard, Department of Horticulture, Faculty of Agriculture, Annamalai University, Annamalainagar during 2013-14 aimed to find out suitable root inducing treatment in mature shoot air-layers of guava cv. L-49. There were 14 treatment combinations with three replications laid out in Randomised Block Design. In general, both growth regulators viz., IBA, NAA alone and in combination with Azospirillum favoured rooting in air-layers. Among the different combinations, the layers which had received Azospirillum $37.5 \mathrm{~g}+$ IBA (Indole butyric acid) $3000 \mathrm{ppm}+$ NAA (Naphthalene acetic acid) $3000 \mathrm{ppm}\left(\mathrm{T}_{12}\right.$ ) recorded significantly higher percentage $(91.68 \%)$ of rooting with desirable root characters such as higher number of primary and secondary roots, longer length of primary roots and higher girth of primary roots. Next to this treatment, the other favorable treatments were IBA, $3000 \mathrm{ppm}+\mathrm{NAA}, 3000 \mathrm{ppm}\left(\mathrm{T}_{6}\right)$, IBA, $2000 \mathrm{ppm}\left(\mathrm{T}_{1}\right)$, Azospirillum 37.5g + IBA, $4000 \mathrm{ppm}\left(\mathrm{T}_{8}\right)$, Azospirillum $37.5 \mathrm{~g}+\mathrm{IBA}, 6000 \mathrm{ppm}\left(\mathrm{T}_{9}\right)$, Azospirillum $37.5 \mathrm{~g}+\mathrm{IBA} 2000 \mathrm{ppm}+$ NAA $2000 \mathrm{ppm}$ $\left(\mathrm{T}_{11}\right)$. The use of medium concentration $(3000 \mathrm{ppm})$ of both the growth regulators (IBA and NAA) with Azospirillum $37.5 \mathrm{~g}$ was more effective as compared to either lower (2000 ppm) or higher $(6000 \mathrm{pm})$ concentrations of IBA and NAA.

KEY WORDS : Plant growth regulator, Azospirillum, Guava, Rooting

HOW TO CITE THIS ARTICLE : Anandhanambi, D., Arivazhagan, E. and Kandasamy, R. (2016). Influence of plant growth regulators and Azospirillum on rooting of air layers in guava (Psidium guajava L.). Asian J. Hort., 11(2) : 261-268, DOI : 10.15740/HAS/TAJH/11.2/261-268. 